\title{
DRUGS AND TRANSPORT PROCESSES
}


1969: Cuthbert: Calcium and Cellular Function

1970: Aldridge: Mechanisms of Toxicity

1971: Rabin and Freedman: Effects of Drugs on Cellular Control Mechanisms

1972: Rang: Drug Receptors 
BIOLOGICAL COUNCIL

The Coordinating Committee for Symposia on Drug Action

\title{
DRUGS AND TRANSPORT PROCESSES
}

A Symposium

\author{
Edited by \\ B. A. CALLINGHAM
}

Department of Pharmacology

University of Cambridge

Macmillan Education 
( Institute of Biology Endowment Trust Fund 1973

Softcover reprint of the hardcover 1st edition 1973

All rights reserved. No part of this publication may be reproduced or transmitted in any form or by any means, without permission

First published 1974 by THE MACMILLAN PRESS LTD

London and Basingstoke Associated companies in New York Melbourne Dublin Johannesburg and Madras

SBN 333168208

ISBN 978-1-349-02275-5 ISBN 978-1-349-02273-1 (eBook)

DOI 10.1007/978-1-349-02273-1 
Biological Council

Coordinating Committee for Symposia on Drug Action

Report of a symposium held on 9 and 10 April, 1973

in London

at The Middlesex Hospital Medical School

Sponsored by

British Pharmacological Society

and

Biochemical Society

British Society for Immunology

Nutrition Society

Physiological Society

Royal Society of Medicine

Society for Endocrinology

Society for Experimental Biology

Organized by a Symposium Committee consisting of

B. A. Callingham (Chairman and Hon. Secretary)
A. W. Cuthbert
I. M. Glynn
W. F. Widdas 


\section{Foreword}

Some while ago now, an unguarded remark set in train a series of events that led up to this particular symposium. Early in 1972 a meeting concerned primarily with the actions of diuretics was being planned but using the present title. A chairman was needed. The word transport, however, can mean different things to different people. To me it meant noradrenaline crossing the neuronal membrane, and I said so.

Of course it was not difficult to fill a two day meeting with papers concerned with transport; the problem was quite the reverse. With the newly decided policy of widening the scope, where could the limit be set? It was not a new problem, the sorcerer's apprentice had seen it before, but had not coped too well. The organizing committee concerned itself, therefore, with transport across epithelia and across the cell membrane, excluding, for example, transport into intracellular components.

The wide spectrum of interests and of expertise is reflected in the following pages, made up, as they are, from all the papers given at the symposium with much of the subsequent discussion. On the first day, diuretics and the kidney were well represented, with an impressive array of data from electrophysiological and biochemical experiments. The authors were able to air their own personal views in front of an audience drawn from many disciplines. This gave a chance for Tom Maren, for example, to take us all on his personally conducted tour of the body's production of acid and utilization of $\mathrm{CO}_{2}$ in his own inimitable style, and to remind us how useful the dogfish is as an experimental animal. The array of experimental tissues was quite bewildering but the red cell was well represented.

The section concerning ionophores reflected the tremendous advances made over the past few years in the attempts to find out how an ion traverses the lipid membrane. No one actually brandished the elusive sodium carrier before the audience but one felt that it could happen at any moment. Likely compounds that could transport ions across lipid membranes were scrutinized minutely. With many of the synthetic ionophores their molecular structures looked so inviting to the tiny cation, encasing it in a protective hydrophobic shell, that the problem looked deceptively simple. Nevertheless, the step from synthetic to natural carrier must inevitably come sooner or later. 
Organic solutes and their transport systems were extensively explored in the last session. Here the biochemical evidence predominated, yielding data on substrate specificity, affinity and the like, for real and aspiring neurotransmitters and their metabolites. Sugar transport in both the red cell and in epithelia gave sufficient kinetic data for model building, while Professor Semenza was able to insert a sugar 'carrier' into the black lipid membrane.

This was the proof, if proof were needed, that this group of scientists had a great deal in common, certainly more than I for one had suspected.

I am very pleased to have the opportunity to record my gratitude to Miss G. Blunt who, yet again, undertook the organization of the symposium. A task she performed with great tenacity and goodwill. My thanks are due also to Mrs A. Prasad, for without her editorial skill, these proceedings would never have seen the light of day. The generosity of the Wellcome Trust allowed us once more the freedom to invite speakers from abroad to our meeting.

B. A. Callingham Cambridge December, 1973 


\section{Contents}

Foreword

List of Participants

Page

vii

$\mathrm{xi}$

1. GIEBISCH, G. The effects of drugs on the electrophysiological properties of kidney tubules

2. CAFRUNY, E. J., KOECHEL, D. A. and NIGROVIC, V. Receptors for mercurial and ethacrynic acid inhibition of sodium chloride transport

3. LANDON, E. J. and MOORE, L. Interaction of diuretics with thiols and cell membranes in kidney tubules

4. ROTHSTEIN, A., KNAUF, P. A., CABANTCHIK, Z. I. and BALSHIN, M. The location and chemical nature of drug 'targets' within the human erythrocyte membrane

5. MAREN, T. H. The relation between renal acidification and bicarbonate reabsorption. A view of $\mathrm{CO}_{2}$-mediated secretion in renal and other epithelia

6. EDELMAN, I. S. Thyroid and sodium transport 101

7. JARD, S. Adrenergic receptors in epithelia

8. TOMLINSON, R. W. S. Some aspects of steroidal action on the isolated frog skin

9. PASSOW, H. and WOOD, P. G. Current concepts of the mechanism of anion permeability

10. CUTHBERT, A. W. Characteristics of sodium channels in transporting epithelia

11. HLADKY, S. B. Pore or carrier? Gramicidin A as a simple pore

12. TRUTER, MARY R. Molecular structures of ionophores and their complexes with metal cations

13. HUNTER, M. J. The use of lipid bilayers as cell membrane models: an experimental test using the ionophore, valinomycin

. FINKELSTEIN, A. Aqueous pores created in thin lipid membranes by the antibiotics nystatin, amphotericin B and gramicidin A: implications for pores in plasma membranes

15. GORDON, L. G. M. Ion transport via alamethicin channels 251

16. IVERSEN, L. L. Neuronal uptake processes for amine and amino acid transmitters 
17. GILLESPIE, J. S. Drugs and ions influencing noradrenaline uptake and accumulation in smooth muscle cells

18. SHARMAN, D. F. The formation of some acidic metabolites in the brain, and their subsequent transport

19. ROOS, B.-E. The effects of drugs on the concentrations of some organic acids in human cerebrospinal fluid

20. SEMENZA, G. The transport systems for sugars in the small intestine. Reconstitution of one of them

21. WIDDAS, W. F. Pharmacological significance of new concepts for hexose transfers in erythrocytes

22. BAKER, G. F. and ROGERS, H. J. The effects of some centrally acting drugs on the hexose transfer system in human erythrocytes

23. MARTIN, K. Effects of lithium on choline transport in synaptosomes and human erythrocytes Index 


\section{List of Participants}

Dr G. F. Baker, Department of Physiology, Bedford College, University of London, Regent's Park, London NW1 4NS, England

Dr A. S. V. Burgen, Medical Research Council, National Institute for Medical Research, Mill Hill, London NW7 1AA, England

Dr E. J. Cafruny, Department of Pharmacology and Therapeutics, Medical College of Ohio, P.O. Box 6190, Toledo, Ohio 43614, USA

Dr B. A. Callingham, Department of Pharmacology, University of Cambridge, Medical School, Hills Road, Cambridge CB2 2QD, England

Dr A. W. Cuthbert, Department of Pharmacology, University of Cambridge, Medical School, Hills Road, Cambridge CB2 2QD, England

Dr I. S. Edelman, Cardiovascular Research Institute and the Departments of Medicine, and of Biochemistry and Biophysics, University of California School of Medicine, San Francisco, California 94143, USA

Dr A. Finkelstein, Departments of Physiology and Neurology, Albert Einstein College of Medicine, Yeshiva University, 1300 Morris Park Avenue, Bronx, New York 10461, USA

Dr G. Giebisch, Department of Physiology, School of Medicine, Yale University, New Haven, Connecticut 06510, USA

Professor J. S. Gillespie, Department of Pharmacology, University of Glasgow, Glasgow G12 8QQ, Scotland

Dr L. G. M. Gordon, Physiological Laboratory, University of Cambridge, Downing Place, Cambridge CB2 3EG, England

Dr D. A. Haydon, Physiological Laboratory, University of Cambridge, Downing Place, Cambridge CB2 3EG, England

Dr S. B. Hladky, Physiological Laboratory, University of Cambridge, Downing Place, Cambridge CB2 3EG, England

Dr M. J. Hunter, Department of Biophysics, University College London, Gower Street, London WC1E 6BT, England

Dr L. L. Iversen, M.R.C. Neurochemical Pharmacology Unit, Department of Pharmacology, University of Cambridge, Medical School, Hills Road, Cambridge CB2 2QD, England

Dr S. Jard, Laboratoire de Physiologie Cellulaire, Collège de France, 11 Place Marcelin Berthelot, Paris 5e, France 
Dr R. D. Keynes, Agricultural Research Council Institute of Animal Physiology, Babraham, Cambridge CB2 4AT, England

Dr E. J. Landon, Department of Pharmacology, School of Medicine, Vanderbilt University, Nashville, Tennessee 37203, USA

Dr T. H. Maren, Department of Pharmacology and Therapeutics, University of Florida College of Medicine, Gainesville, Florida 32610, USA

Dr K. Martin, Department of Pharmacology, University of Cambridge, Medical School, Hills Road, Cambridge CB2 2QD, England

Professor H. Passow, Department of Cell Physiology, Max-Planck-Institut für Biophysik, 6 Frankfurt a.M.70, Kennedyallee 70, Germany

Dr B.-E. Roos, Department of Pharmacology, University of Göteborg, Fack, S-400 33 Göteborg 33, Sweden

Dr A. Rothstein, Division of Cell Biology, The Research Institute, The Hospital for Sick Children, 555 University Avenue, Toronto 2, Ontario, Canada

Professor G. Semenza, Laboratorium für Biochemie, Eidgenössische Technische Hochschule, Universitätstrasse 16; CH8006 Zürich, Switzerland

Dr D. F. Sharman, Agricultural Research Council Institute of Animal Physiology, Babraham, Cambridge CB2 4AT, England

Dr R. W. S. Tomlinson, Department of Medicine, King's College Hospital Medical School, Denmark Hill, London SE5 8RX, England

Professor M. R. Truter, Molecular Structures Department, Rothamsted Experimental Station, Inveresk House, 346 Strand, London WC2R 0HG, England

Professor W. F. Widdas, Department of Physiology, Bedford College, Un:versity of London, Regent's Park, London NW1 4NS, England 